УДК 37.014.53 (477.7) «1941-1944»

DOI: https://doi.org/10.33782/eminak2019.2(26).294

\title{
СОЦІАЛЬНО-ЕКОНОМІЧНА ПОЛІТИКА РУМУНСЬКОЇ АДМІНІСТРАЦІЇ У СІЛЬСЬКІЙ МІСЦЕВОСТІ ПІВДЕННО-ЗАХІДНОЇ УКРАЇНИ В 1941-1944 pp.
}

\author{
Олександр Осипенко \\ Одеський національний морський університет (Одеса, Україна) \\ e-mail: OsupenkoOleksandr@ukr.net \\ ORCID: https://orcid.org/0000-0002-1213-0481
}

\begin{abstract}
У статі проаналізована соціально-економічна політика румунської адміністрації щодо сільського населення у межиріччі Дністра та Південного Бугу в 1941-1944 роках. Встановлено, що з перших днів окупації румунське керівництво перейшло до відвертого грабування сільського населення. Для сільського населення було розроблено та впроваджено низку натуральних податків. Румунське керівництво на окупованих землях південно-західної України зберегло створену сталінським керівнищтвом довоєнну систему оплати праці «трудодень». Оплата праці сільських трудівників носила натуральний характер. Із селянами розраховувались тими видами сільськогосподарських продуктів, які вирощували «трудові громади».
\end{abstract}

Ключові слова: Трансністрія, окупація, повіт, сільське населення, трудова громада, накази, податок

Попри нові виклики сьогодення, період минулої війни й окупації залишається однією з найбільш гострих в українському суспільстві тем. Серед дослідних лакун, зон розламу в історіописанні Другої світової війни в Україні є румунська окупаційна політика, яка реалізовувалася на південно-західних теренах і, зокрема, на селі. Однією з таких прогалин, що актуалізує наше дослідження, є соціально-економічна політика румунської адміністрації щодо сільського населення у межиріччі Дністра та Південного Бугу в 1941-1944 pp.

Стосовно історіографії порушеного питання слід зазначити, що науковці у своїх дослідженнях фрагментарно підійшли до його вивчення. У зарубіжній історіографії цієї проблеми торкнулися американський дослідник О. Даллін ${ }^{1}$, молдавська дослідниця Р. Соловей 2 і російський історик О. Будницький ${ }^{3}$. Радянська історіографія цього питання представлена дослідженнями М. Лєбєдєва 4 , I. Левіта ${ }^{5}$, С. Гратинича6. Україн-

\footnotetext{
${ }^{1}$ Dallin A. Odessa, 1941-1944: A Case Study of Soviet Territory Under Foreign Rule. - RAND, RM -1875: California, 1957. $466 \mathrm{p}$.

2 Solovei R. Activitatea Guvernamintului Transnistriei on domeniul social-economic si cultural: (19 auq. 1941 - 29 ian. 1944). Iasi, 2004. 182 p.

3 Одесса: жизнь в оккупации. 1941-1944. История коллаборационизма. Москва: Политическая энциклопедия, 2013. 231 с.

4 Лебедев Н.И. Крах фашизма в Румынии. Москва: Наука, 1976. 632 с.

5 Левит И.Э. Крах политики агрессии диктатуры Антонеску. Кишинев : Штиинца, 1983. 376 с.

6 Гратинич С.А. На левом берегу Днестра 1941-1944. Страницы совместной борьбы трудящихся смежных районов Молдавии и Украины против немецко-румынских фашистских захватчиков. Кишинев: Картя Молдовеняскэ, 1985. 186 с.
} 
ські історики В. Щетніков 7 та О. Перехрест ${ }^{8}$ також зачепили даний аспект, але у своїх дослідженнях переймалися переважно розглядом економічних збитків від окупації. Колектив дослідників очолений Миколою Михайлуцою, подав загальну характеристику адміністративно-територіального поділу, соціально-економічного становища та культурного життя «Заддністрянщини» у період 1941-1944 pp. ${ }^{9}$ М. Михайлуца на сторінках своєї монографії, розглянув соціально-економічну політику румун щодо православного кліру на теренах «Трансністрії»10. В іншому дослідженні науковець, використавши румуномовні архіви, не тільки реконструював діяльність, а й розглянув соціально-економічну буденність одного з південноукраїнських осередків православ'я - Доманівського субпротоієрейства Голтського повіту11. Деякі аспекти соціально-економічної політики румунської адміністрації на теренах Південно-Західної України розглянув у своїх дослідженнях 0. Осипенко ${ }^{12}$.

Метою дослідження є соціально-економічна політика румунської адміністрації у сільській місцевості Південно-Західної України в 1941-1944 рр.

Особливе місце у планах окупантів займали сільськогосподарські землі ПівденноЗахідної України, які після домовленостей А. Гітлера й І. Антонеску 30 серпня 1941 р. у Тігіні (зараз - Бендери), були віддані в управління румунам. До «Трансністрії» було включено лівобережні райони Молдавії, Одеську область в її тодішніх адміністративних межах, західні райони Миколаївської та південні райони Вінницької областей України. До 17 жовтня 1941 р. адміністративним центром був Тирасполь, а згодом Одеса. Територію губернаторства було поділено на 13 повітів: Ананіївський, Балтський, Березівський, Голтський, Дубосарський, Жугастрівський, Могилівський, Овідіопольський, Одеський, Очаківський, Рибницький, Тираспольський, Тульчинський 13 .

Повіти було поділено на претури (райони), усього у губернаторстві було 64 райони ${ }^{14}$. Кількість претур у повіті коливалась у межах від 4-х до 6-ти. У свою чергу претури було поділено на адміністративно-територіальні одиниці - комуни (рум. Comynei), які складалися з кількох десятків населених пунктів ${ }^{15}$.

На відміну від губернаторств Бессарабії та Буковини, якими керували винятково військові, керівником «Трансністрії» було призначено цивільну особу - професора Г. Алексяну. До обов’язків губернатора входило: управління адміністрацією та кому-

\footnotetext{
7 Щетніков В.П. Економічна складова румунсько-німецької присутності в «Трансністрії» 19411944 рр. // Сторінки воєнної історії України. 2012. Вип. 15. С. 173-188.

8 Перехрест О.Г. Сільське господарство України в роки Великої Вітчизняної війни (1941-1945рр.). Київ: Інститут історії України НАН України, 2010. 150 с.

9 Окупаційний режим в губернаторстві «Трансністрія» / Т. Вінцковський, Г. Кязимова, М. Михайлуца, В. Щетніков // Україна у Другій світовій війні: погляд з XXI ст. Історичні нариси. Київ: Наукова думка, 2010. Т. 1. С. 413-446.

10 Михайлуца М.I. Православна церква на Півдні України в роки Другої світової війни (1939-1945). Одеса: Вид-во «ВМВ», 2008. 329 с.

11 Михайлуца М.I. Реконструкція діяльності Доманівського протоієрейства Голтянського повіту в період румунської окупації (1941-1944рр.) // Краєзнавство. 2015. № 1-2. С. 184-189.

12 Осипенко О.В. Сільське населення та «Трудові громади» Півдня України в губернаторстві «Трансністрія» 1941-1944 рр.: соціально-історичний аспект: автореф... к. іст. н.: 07.00.01 - історія України. Миколаїв, 2018. 20 с.

13 Жуковський А. Українські землі під румунською окупацією в часи Другої світової війни: Північна Буковина, частина Бессарабії і Трансністрії // Український історик. 1987. № 1-4. С. 87.

14 Рекотов П.В. Органи управління на окупованій території України (1941-1944рр.) // Український історичний журнал. 1997. № 3. С. 97.

15 Дейнека Н. Румунський окупаційний режим та радянський рух Опору у південно-західному регіоні України і Молдавії (1941-1944 рр.). Одеса: Атлант, 2013. С. 41.
} 
нікаціями, управління агрокультурою й економікою, управління освітою, культом і пропагандою, управління громадськими роботами, фінансове управління 16 .

Декретом від 19 серпня 1941 р. було організовано дирекції (адміністрації) фінансів, освіти, комерції, шляхів сполучення і зв'язку, агрокультури, економіки, охорони здоров'я, культів і пропаганди тощо. 3 часом, виходячи з окупаційних планів румунської адміністрації, їх кількість постійно збільшувалася. Згідно із цим декретом чиновники, які направлялися на роботу до губернаторства, отримували подвійну заробітну платню у леях і марках ${ }^{17}$.

Повіти (рум. judet), очолювані префектом, підпорядковувалися губернатору. У підпорядкуванні префекта перебували начальники жандармерії легіону та поліції міських комун, також він ніс всю відповідальність у своєму окрузі за дотримання законодавства на місцевому рівні. До його обов'язків, поміж іншого, входили дві основні функції: перша - передача наказів губернатора до нижчих інстанцій, друга контроль за відповідними органами управління на підпорядкованій йому території. В управлінні префектурою чиновнику допомагали два помічники - суб-префекти (прім-префект), один із яких мав бути місцевим. Головною функцією останніх було здійснювати керівництво управлінським апаратом префектури, перегляд і зміна судових рішень нижчих інстанцій - преторів і примарів 18.

Повіти було поділено на претури (райони), які очолювали претори. Кількість претур у повіті коливалась від 4-х до 6-ти, і включали у себе комуни. Претори, у свою чергу, очолювали відділи сільського та лісового господарства, освітній, технічний, санітарний і ветеринарний відділи, а також керували волосною поліцією та мали у своєму підпорядкуванні жандармерію. Другою особою після претора був примпретор, на якого покладались функції координатора всіх місцевих адміністративних установ, здійснення контролю над їхніми відділами та нагляду за виконанням наказів претора та вищих інстанцій ${ }^{19}$. Претури забезпечували діяльність податкової системи, системи штрафів, контролювали усю торгівлю, промисловість і сільське господарство Трансністрії 20.

Оскільки місцевому населенню окупанти не довіряли, то у містах і селах були створені міські та сільські управи (примарії), на чолі яких у місті був голова (мер), а в селі - староста. Вони й вирішували всі загальні справи місцевого значення. Старости спиралися на допомогу секретаря, нотаря (сільський писар, який виконував функцію заступника примаря), агронома, інженера й інших посадовців, виконував чи не єдине завдання - впроваджувати у життя всі накази, постанови, доручення й інші нормативно-правові акти вищих інстанцій на підконтрольній йому території21.

Основні функції управління сільським господарством виконувала дирекція агрокультури. Цей орган керував процесом оброблення землі, вирощування худоби та

\footnotetext{
16 Тарнавський І.С. Політика Третього рейху та його союзників на окупованих українських землях в роки Другої світової війни. Донецьк: ТОВ «ВПП «ПРОМІНЬ», 2012. С. 152.

17 Одесская область в Великой Отечественной войне 1941-1945 гг.: Док. и матер. / отв. ред. Н.И. Зотов и др. Одесса: Маяк, 1970. С. 159.

18 Левченко Ю. Управлінський апарат румунських адміністративно-територіальних одиниць України під час окупації 1941-1944 pp. // Науковий вісник Східноєвропейського національного університету ім. Лесі Українки. Серія: історичні науки. Луцьк, 2013. Вип. 21 (269). С. 72.

19 Левченко Ю. Вказ. праця. С. 72-73.

20 Ніточко І.І. Окупація: Березівський район. 1941-1944 pр. Одеса: Астропринт, 2008. С. 276.

21 Тарнавський І.С. Адміністративний поділ та органи управління на території південно-західної України за часів румунської окупації // Історичні і політологічні дослідження. 2010. № 3-4. С. 214.
} 
сільськогосподарської продукції, розподілом урожаю та продуктів, отриманих від тваринництва. У своїй діяльності на місцях дирекція спиралася на, так звані, «трудові громади» та «державні ферми». Переважно, як свідчать джерела, вони виникли на основі колишніх колгоспів і радгоспів, шляхом зміни тільки назви. Значна роль відводилась машинно-тракторним станціям, на які припадало основне навантаження механічного обробітку землі, збирання урожаю тощо. Поряд із тим, дирекція агрокультури опікувалася придбанням будівельних матеріалів, інструментів, усіх необхідних машин і механізмів для землеробської та сільськогосподарської діяльності22.

Одним з перших кроків окупаційної влади щодо керівництва захопленими територіями став наказ № 2, який було розроблено на основі декрету № 1 від 19 серпня 1941 р., підписаного Г. Алексяну у м. Тігіні (зараз м. Бендери). Цим наказом усі особи, які до війни займали керівні посади або виконували функції відповідно до суспільного значення, чи то у колгоспах чи радгоспах, зобов'язувалися терміново з'явитися до місцевих адміністративних органів влади, де уповноважені особи мали знову затвердити їх на займаних раніше посадах. Такі особи повинні були негайно продовжити свою попередню діяльність. Ті особи, які «відмовлялися з'явитися або відхрещувалися виконувати постанови, підлягали покаранню за саботаж»23.

У березні 1942 р. наказом № 55 цивільного губернатора Г. Алексяну, окупаційна адміністрація до проведення аграрної реформи, підтримала функціонування упродовж перших місяців, колгоспів і радгоспів у такому вигляді, якими вони були за радянської влади. Для цього сільські примарі проводили відповідні зібрання, рішення яких зобов'язали завідувачів колгоспів і бригадирів приступити до виконання своїх обов'язків у тих місцях, де вони були. Після затвердження на посаді, керівники колгоспів мали скласти опис всього майна, живого та мертвого інвентарю, який знаходився у колгоспах і радгоспах, та прийняти всі необхідні заходи для його збереження.

Згідно з наказом оголошувалося, що остаточний розподіл землі буде здійснено після встановлення миру, тобто після перемоги над більшовизмом. Також мала відбутися ліквідація колгоспів, й утворення на їх місці «трудових громад» з експлуатації землі. 3 кожної «трудової громади» передбачалося утворити бригади по 10-20 членів домогосподарств, які за можливістю мали перебувати у родинних стосунках. Керівництво бригадою був зобов'язаний здійснювати начальник (старшина), якого обирали з місцевих мешканців 24 .

Управління кожною з бригад довірялося одному керівнику, який обирався із членів бригади, та праця якого мала бути компенсована грошима або оплачена натурою, відповідно до окремого розпорядження. Цей керівник був відповідальною особою перед членами бригади, а також перед Румунською державою за виконану роботу 25 .

Із перших днів окупації земель південно-західного регіону України румунська адміністрація чималі зусилля направила на розробку та впровадження у життя наказів і постанов, спрямованих першочергово на викачування стратегічно важливих і необхідних сільськогосподарських ресурсів як для забезпечення власної продовольчої безпеки, так і потреб Німеччини й Італії.

\footnotetext{
22 Державний архів Миколаївської області (ДАМО). Ф. 1672. Оп. 1. Спр. 243. Арк. 2.

23 Державний архів Одеської області (ДАОО). Ф. 1932. Оп. 1. Спр. 544. Арк. 13.

24 ДАМО. Ф. 1721. Оп. 1. Спр. 65. Арк. 12.

25 ДАОО. Ф. 1932. Оп. 1. Спр. 697. Арк. 67.
} 
Не встигли окупанти оговтатися від ейфорії захоплення Одеси, як на 1 листопада 1941 р. губернатор «Трансністрії» Г.Алексяну відзвітував перед маршалом I. Антонеску про успішно проведену реквізицію сільськогосподарської продукції. За даними звіту губернатора упродовж жовтня до Румунії для забезпечення їі потреб було відправлено: 23,5 тис. голів великої рогатої худоби на загальну суму 470 млн. лей, 20 тис. каракулевих овець, загальна вартість яких було оцінено в суму 40 млн. лей. У королівство також було відправлено 10 тис. кг вовни вартістю 2 млн. лей, 150 вагонів збіжжя (пшениця, просо, ячмінь) вартістю 15 млн. лей, шкіряної сировини - 2,5 вагони на суму 1 млн. 250 тис. лей. Загальна вартість вивезеної до Румунії худоби та сировини становила 627 млн. 250 тис. лей. Окрім зерна та сільськогосподарської продукції окупанти вивезли з південноукраїнських земель насіннєвий матеріал, саджанці тощо 26.

Врахувавши власні економічні проблеми, а також значні економічні зобов'язання перед своїми союзниками - Німеччиною й Італією, зокрема, у поставках сільськогосподарської продукції як для внутрішніх, так і військових потреб, румунська влада значну частину цього тягаря вирішила перекласти на місцеве населення, яке мешкало на території новоствореного губернаторства «Трансністрія». Тому й не дивно, що відразу після встановлення окупаційної влади на плечі сільських жителів лягли грошові та натуральні податки.

Наказом губернатора № 66, для забезпечення окупаційних військ, колгоспників і працівників радгоспів зобов'язали здавати птицю, свинину, молоко, бринзу та мед. Наказ стосувався усіх господарств, незалежно від того, вироблялась дана продукція у цих господарствах чи ні. Зокрема, було встановлено чітку кількість названих видів сільськогосподарської продукції. Так, господарства, що мали у своєму розпорядженні до 10 шт. курей, мали здавати, відповідно, одну птицю та 10 яєць із курки; від 11 до 20 шт. - зобов’язувалися здати 3 птиці; від 21-25 шт., відповідно 5 курей, а в тих подвір'ях, де було понад 25 голів птиці - по 10 курей.

Окрім дрібної птиці, у вказаному наказі № 66, населення обкладалось податком на молоко та молочні продукти. Кожна селянська родина, яка тримала корів, зобов'язана була здавати молоко, у таких пропорціях: сім'я з двох осіб здавала 300 л молока, родина, яка мала у своєму складі понад дві особи, зобов'язувалася здавати 150 л молока. Оскільки наказ № 66 часто поширювався у рукописному варіанті, цифрові норми виявлялися завищеними, що, на нашу думку, місцеві чиновники робили навмисно, гарантуючи таким чином загальне виконання обсягів поставок.

Селяни, у власності яких були вівці або бджолині сім'ї, мали здавати 2 кг бринзи 3 вівці, 4 кг меду з рамкового вулика та 1 кг цього продукту з дуплявого 27.

Отже, на всі основні види сільськогосподарської продукції, що вироблялася у селянських господарствах, було встановлено обов'язкове натуральне оподаткування.

Для населення, яке з різних причин не виконувало наказів, органи окупаційної влади повсякчасно застосовували систему покарань. Серед найпоширеніших заходів румунські окупанти використовували арешт на різний термін ув'язнення, залякування, тиск, побиття тощо. Однак, дієвим і вигідним для самих окупантів було вилучення поголів'я худоби (корів, овець тощо). За таких обставин господарства втрачали годувальниць і, власне, надію на виживання.

\footnotetext{
26 Лебедев Н.И. Крах фашизма в Румынии. Москва: Наука, 1976. С. 299.

27 ДАОО. Ф. 1932. Оп. 1. Спр. 2797. Арк. 5-6.
} 
За даними дослідника I. Левіта, після розміщення на теренах між Бугом і Дністром 3-ї та 4-ї румунських армій, розгромлених у 1943 р. Червоною армією під Сталінградом, румунське військове командування вимагало для додаткового забезпечення цих військ 885 вагонів пшениці, 112 вагонів цукру, 1540 тонн соняшникової олії, 35437 голів худоби. Задля виконання цих вимог адміністративний апарат видав низку наказів для впровадження нових і підвищення обсягів старих податків. Так, у наказі № 115/943 губернаторства «Трансністрії» мова йде про те, що кожен сільський мешканець був зобов'язаний здати 50 кг м'яса, для цього селяни вимушені були спільно купувати худобу та живою здавати ії окупаційній владі28.

Наскільки обтяжливим для селянина був визиск, свідчать наведені нижче приклади. Так, мешканець села Тановка Березівського району А.Ф.'Мокану у вигляді грошового податку за 1943 р. здав окупантам: земельного податку - 99 марок, податок із городу - 72 марки, податок із корови - 30 марок і податок на «культурні потреби» у розмірі 30 марок. Таким чином, тільки за чотирма видами податку цей селянин заплатив 231 марку. Окрім грошового податку, цей колгоспник здав натурального податку у вигляді молока - 300 літрів, м’яса - 50 кг та яєць 108 шт.29.

Господар общинного двору № 2 1-ї ділянки м. Ананьєва Кольчак Андрій, родина якого складалася з 9 осіб і мала у власності корову та три вівці, у 1943 р. здав 150 л молока та 8 кг бринзи у вигляді натуральних податків та оплатив земельний податок у розмірі 98,5 марок. Балабан Анна цієї ж ділянки здала 300 л молока та виплатила земельного податку в розмірі 30 марок. Родина Чебана Василя з 5 осіб, маючи у своєму розпорядженні 1 корову та 3 вівці, сплатила у вигляді натуральних податків хоча удвічі менше молока, але вже 12 кг бринзи та грошового податку за землю 65 марок ${ }^{30}$. Крім вищезазначеної сільськогосподарської худоби, у цих господарствах через скруту більше нічого не трималося.

Зовсім інші норми податків лягли на плечі мешканців «трудової громади» № 24 с. Качуровки Долинської претури, зокрема, сільські трудівники на вимогу загарбників здали м'яса трьох видів тварин (свинину, яловичину та баранину), курей, яйця, молоко, мед і вовну. Так, господар Сагайдак Д. сплатив такі види натуральних податків: яловичини - 30 кг, свинини - 10 кг, баранини - 10 кг, 2 курей, яєць - 100 штук, бринзи - 8 кг, молока - 250 л і 3 кг вовни. Собитняк М. сплатив: яловичини - 30 кг, свинини - 10 кг, баранини - 10 кг, 4 курки, яєць - 200 штук, бринзи - 16 кг, молока 250 л, меду - 10 кг і 6 кг вовни 31.

Реконструкція податкової системи на прикладі декількох окремо взятих адміністративних одиниць - примарії та «трудової громади», дає змогу відтворити схему окупаційного визиску та їі складові. Так, мешканці Бернадівської примарії Березівської претури, яка включала у себе села Бернадівку та Красний агроном, здали такі податки: селяни Бернадівки станом на 1943 р. здали губернаторству 45 гусей, 5 качок, 448 курей і 23000 яєць. А жителі села Красний агроном - гусей 13 шт., качок 4 шт., курей - 66 та яєць - 3500 шт. Назагал 247 господарств цих двох сіл мали курей. У 12 господарствах взагалі не було цього виду птиці, тому для них було визначено іншу норму здачі курей, а саме 12 курей і 1200 шт. яєць.

Крім вищезазначених сільськогосподарських продуктів мешканці примарії пови-

\footnotetext{
28 Левит И.Э. Крах политики агрессии диктатуры Антонеску. Кишинев : Штиинца, 1983. С. 167.

29 Одесская область в Великой Отечественной войне 1941-1945 гг.... С. 179.

30 ДАОО. Ф. 1932. Оп. 1. Спр. 42. Арк. 13.

31 ДАОО. Ф. 1932. Оп. 1. Спр. 1051. Арк. 29.
} 
нні були здати 419 кг овечої вовни, проте поставити змогли тільки 375 кг, причиною недовиконання став від'їзд на постійне місце проживання до іншого населеного пункту громадянина Абухіна, у власності якого було 3 вівці. Станом на 5 жовтня 1943 р. мешканцями примарії також було виконано план здачі меду у розмірі 125 кг ${ }^{32}$.

Із мешканців «трудової громади» № 24 с. Качуровки Долинської претури за наказом окупаційної адміністрації наприкінці 1943 р. було зібрано: яловичини - 1050 кг, свинини - 350 кг, баранини - 350 кг, курей - 81 шт., яєць - 4100 шт., бринзи - 140 кг, молока - 7750 л, меду - 49 кг та 52,5 овечої шерсті ${ }^{33}$.

Із зазначеного вище можна констатувати, що незважаючи на час військового лихоліття та перебування в окупації, сільські мешканці й надалі продовжували за можливості тримати у власних господарствах свійських тварин і птицю, наявність яких давала можливість господарям забезпечити свої родини найнеобхіднішими продуктами харчування та убезпечити їх від голодної смерті. Проте здирницька, непродумана та недалекоглядна податкова політика румунської влади, призводила до того, що селяни задля виконання норм податків вимушені були різати всю наявну у них худобу, що призводило до погіршення й так складного життя сільських трудівників, а сама окупаційна адміністрація у подальшому втрачала можливість взагалі отримувати будь-які види натуральних податків.

Підокупаційне населення також змушене було сплачувати податок за випас своєї худоби на землях громади. Наприклад, випас великої рогатої худоби обходився селянинові у 10 марок на рік, а випас дрібної рогатої худоби (овець і кіз) - удвічі менше. До того ж, лише десята частина із зібраної суми податку залишалася товариству, а 90\% йшло на потреби окупантів ${ }^{34}$.

Сільські трудівники, й до того переобтяжені сплатою різноманітних натуральних сільськогосподарських податків, не маючи іншого виходу, змушені були виконувати і цей наказ окупантів. Наприклад, мешканці трудової громади № 2 Голтянського сільського повіту за випас корів заплатили 168 марок тільки у травні 1942 р.35.

Кожен селянин зобов'язувався мати довідку на володіння худобою. За отримання цього документа він змушений був заплатити згідно із прейскурантом: 5 марок за велику рогату худобу та 2 марки за дрібну худобузб.

Окупаційна адміністрація не залишила поза увагою і тих селян, які тримали собак, увівши для цієї категорії мешканців спеціальний податок. Зокрема, господарі були зобов'язані зареєструвати своїх собак та отримати на кожного номер. Під час реєстрації тварин вносилась плата за непородистого собаку - 2 марки, за породисту тварину сторожової породи - 3 марки на рік ${ }^{37}$. Проте селяни не поспішали виконувати даний наказ. Наприклад, за мешканцями «трудової громади» № 24 с. Качуровка за 1942 р. залишився борг у розмірі 93 марки через несплату податку за утримання 31 собаки ${ }^{38}$. На нашу думку, селяни ігнорували сплату даного податку у зв'язку з тим, що окупаційна влада на законодавчому рівні не прописала норми покарання за

\footnotetext{
32 ДАОО. Ф. 2377. Оп. 1. Спр. 207. Арк. 1, 3, 14, 16.

33 ДАОО. Ф. 1932. Оп. 1. Спр. 1051. Арк. 3.

34 ДАОО. Ф. 1932. Оп. 1. Спр. 1148. Арк. 45.

35 ДАМО. Ф. 2540. Оп. 1. Спр. 19. Арк. 12.

36 Левит И.Э. Крах политики агрессии диктатуры Антонеску. С. 313.

37 ДАОО.Ф. 1932. Оп. 1. Спр. 674. Арк. 262.

38 ДАОО. Ф. 1932. Оп. 1. Спр. 1051. Арк. 49.
} 
невиконання даної постанови. А у випадку наявності покарання, господар завжди міг позбутися цієї тварини, враховуючи те, що собака не становив ніякої цінності порівняно з тією ж коровою, яка була справжньою годувальницею та рятівницею людських життів у часи лихоліть.

Крім перерахованих вище різноманітних натуральних податків, румунська адміністрація зобов'язала сільське населення також здавати птицю, молоко, м'ясо на потреби армії. На нашу думку, було декілька причин проведення такої політики. Зокрема, чиновники губернаторства, вислуговуючись перед вищим керівництвом Румунії, не мали бажання псувати загальної картини виконання поставок сільськогосподарської продукції, тому й вирішили перекласти на плечі населення ще й обов'язок забезпечення необхідною продукцією окупаційні війська. Ще однією причиною могло бути те, що влада зі свого боку, через економічну виснаженість відповідних територій, не мала змоги забезпечити виконання поставок необхідної сільськогосподарської продукції для потреб військових, тому й вирішила скинути цей клопіт на селян. Так, на основі наказу Мостовської претури за № 928 від 17 березня 1943 р. «трудова громада» № 3 Градовської сільської управи на потреби армії здала 35 гусей $^{39}$. А «трудова громада» № 88 за розпорядженням Кривозерської претури виділила на потреби армії 10 га люцерни, яку сама ж була зобов'язана скосити 40 .

Фактично вся сільськогосподарська продукція, що збиралася на території «Трансністрії» у вигляді натуральних податків, відправлялася першочергово на забезпечення військових потреб Румунії та її союзників.

За даними дослідника С. Гратинича з губернаторства «Трансністрія» до Румунії 3 10 вересня до 1 листопада 1942 р. було відправлено 32956 вагонів зерна та майже 13 тисяч вагонів продовольчих товарів ${ }^{41}$.

Історик І. Левіт наводить дані, згідно з якими станом на 1 січня 1943 р. з території «Трансністрії» до Румунії було відправлено 16169 вагонів зерна, 2399 вагонів овочевих культур, 30362 голів худоби, 3611,1 вагонів фуражу на загальну суму 6,1 млрд. лей. На харчування румунської армії: зерна - 21450 вагонів, овочів - 14106 вагонів, продовольства - 1873,7 вагонів, фуражу - 41123 вагонів, худоби - 172283 голови, птиці - 519937 голів на загальну суму 12,3 млрд. лей.

Маючи економічні зобов'язання перед своїми союзниками, на потреби німецької армії станом на 1 січня 1943 р. було відвантажено зерна 9017 вагонів, овочів - 6250 вагонів, худоби - 93174 голів, птиці - 211072 голів тощо на загальну суму 5,6 млрд. лей. Італійська армія отримала 15935 голів худоби, 53260 голів птиці, загальна сума поставок склала 607,2 млн. лей ${ }^{42}$.

У період з 1 вересня до 20 листопада 1943 р., згідно зі звітом губернатора «Трансністрії» Г. Алексяну, було вивезено до королівства 11 051,5 вагонів зерна, 2 381,5 вагонів продовольчих товарів; для румунської армії передано 8238,2 вагонів зерна. За неповними даними $з 4$ листопада до 9 грудня того ж року з «Трансністрії» було вивезено 136,1 тис. голів різного виду тварин, 7721 вагонів селекційного насіння 43.

Згідно з повідомленням румунського генерального штабу в губернаторство

\footnotetext{
39 ДАМО. Ф. 2469. Оп. 1. Спр. 67. Арк. 22.

40 ДАМО. Ф. 2574. Оп. 1. Спр. 24. Арк. 28.

41 Гратинич С.А. Вказ. пр. С. 51.

42 Левит И.Э. Участие фашистской Румынии в агрессии против СССР. Истоки, планы, реализация.

Кишинев: Штиинца, 1981. С. 306.

43 Левит И.Э. Крах политики агрессии диктатуры Антонеску. С. 195, 201.
} 
«Трансністрія» про вивіз продовольства та майна із «Трансністрії» у період 3 1 листопада по 14 грудня 1943 р., до Румунії було відправлено: вершкового масла - 3 вагони, цукру - 154 вагони, зернових (пшениця, жито, ячмінь, овес і кукурудза) 1204 вагони (кожен вагон містив по 10 тонн) та 173870 голів тварин (корів, овець, свиней птиці та кролів) ${ }^{44}$.

Український дослідник О.Перехрест вважає, що на початок 1944 р. румунські окупанти із «Трансністрії» до королівства вивезли 10154 вагони різних вантажів, переважно із продовольством, і 217 тис. голів великої рогатої худоби та декілька десятків тисяч іншої худоби 45 .

На наш погляд, цілком слушною є думка дослідника І. Левіта, згідно з якою не можна скласти точної картини щодо реквізованої продукції, оскільки провізія реквізовувалася військовими частинами, які не давали звіту місцевим органам влади, особливо у перші місяці окупації. Не було також і повного звіту з тієї причини, що союзники у своїх взаємних розрахунках намагалися приховати один від одного, що саме і в якій кількості ними було реквізовано та вивезено за межі губернаторства ${ }^{46}$.

На початку воєнної кампанії румунська пропаганда підкреслювала, що створена Й. Сталіним колгоспна система $є$ неприйнятною й буде одразу ж зруйнована встановленою адміністрацією, а селянство перейде до вільного господарювання на власній землі.

Першим кроком нової влади задля забезпечення виконання поставленої мети стає оприлюднення наказу № 56 губернатора «Трансністрії» Г.Алексяну від 18 березня 1942 р., який регламентував, що праця, відповідно до аграрного порядку, залишається обов'язковою на усій території губернаторства. Усе працездатне населення - чоловіки, жінки та діти - було залучено в організацію громадської праці та зобов'язувалися працювати на основі встановлених владою норм і планів.

Ті представники населення, які відмовлялися виконувати настанови цього наказу, підлягали низці покарань, які мали відповідну градацію: за відмову працювати у визначених умовах відправляли до трудового табору терміном до 2-х років; ті, хто перешкоджав організації праці, нищили повністю або частково різного роду інвентар та обладнання, робили його непридатним для використання - підлягали тюремному ув'язненню терміном від 1 до 3 років. Водночас, у випадку провокування до злочинних дій інших, підбурювачам загрожувало позбавлення волі на 3 роки; від 3 до 10 років могли отримати працівники за заклики до непокори, ухиляння від обов'язкової праці та ворожих дій проти влади; мешканцям, які здійснювали насилля або погрози відносно до влади з метою перешкоджання трудовій діяльності тощо - загрожувало ув'язнення терміном від 5 до 20 років ${ }^{47}$.

Через декілька днів керівництво видає нову постанову, в якій з 20 березня 1942 р. у губернаторстві «Трансністрія» було запроваджено обов'язкову трудову повинність для всіх жителів віком від 16 до 60 років, що стало ще одним тягарем для населення окупованого краю. Щодо його долі, зазначалось, що мешканці «будуть по черзі ви-

\footnotetext{
44 Одесса в Великой Отечественной войне Советского Союза: Сб. док. и матер. в 3-х т. / отв. ред. И.В. Бортников. Т. 2: 17.10.1941 - 9.4.1944. Одесса: Одесское областное издательство, 1969. С. 7071.

45 Перехрест О.Г. Сільське господарство України в роки Великої Вітчизняної війни (19411945 рр.). Київ: Інститут історії України НАН України, 2010. С. 64.

46 Левит И.Э. Участие фашистской Румынии в агрессии против СССР. С. 305.

47 ДАМО. Ф. 1721. Оп. 1. Спр. 65. Арк. 12.
} 
користані на різних роботах військового характеру, на роботах для установ і підприємств громадських і приватних, а також на сільськогосподарських роботах термінового характеру. Звільнялися від трудової повинності лише ті, хто працював у громадських закладах або у приватних підприємствах, учні та студенти на період занять, особи вільних професій, комерсанти та підприємці, які мали дозвіл; хворі, вагітні, (терміном від 5 місяців); жінки з дітьми до 5 років та жінки, які мали більше 3 дітей до 10 років. За неявку на роботу населення каралось позбавленням волі у таборі від одного місяця до одного року та штрафом від 50 до 300 марок48.

На нашу думку, наявність зазначених постанов свідчить про те, що адміністрація губернаторства «Трансністрія» такими жорсткими заходами робила спробу унеможливити зрив вдалого проведення весняно-посівної кампанії, реалізувати яку було неможливо без використання робочих рук сільських трудівників. Сільські мешканці, не маючи іншого виходу, змушені були працювати на ворога, чудово розуміючи, що відмова або саботаж призведе до неодмінного ув'язнення, що негативно вплине на погіршення й до того складного матеріального становища їхніх родин.

Для вчасного виконання сільськогосподарських робіт у період весняно-літніх польових і господарських робіт все працездатне населення зобов'язувалось стати до роботи о п’ятій годині ранку. Закінчувався робочий день о восьмій годині вечора, обідня перерва тривала з 12:00 до 13:00 години. Старости «трудових громад», бригадири, а також дільничні агрономи зобов'язувалися закріпити за кожним працездатним норми виконання робіт 49 .

Румунською адміністрацією було збережено й радянську форму оплати праці «трудодень», який обраховувався за виконання різних категорій праці. Останні розподілялися відповідно до складності на дев'ять - від найпростішої праці: скошування, прибирання, догляд за худобою, до найскладнішої - дев'ятої категорії, наприклад, праця тракториста, без якого неможливі сільськогосподарські операції. Цей залишковий принцип оплати праці сільських працівників передбачав встановлення вартості одного трудодня наприкінці сільськогосподарського року, коли була визначена сума продуктів і грошей, що залишилися після наступного розподілу. Так, $20 \%$ мало йти на закладання насіннєвого фонду, частину повинні були здавати до кормового фонду тварин, які належали громаді, а 10\% зібраного урожаю - спрямовувалось на утримання адміністрації громади, і лише 1\% на утримання інвалідів і сиріт віком до п'ятнадцяти років.

Обов'язковою була оплата за користування технікою машинно-тракторних станцій (MTC), незалежно від того, чи були виконані технічні роботи повністю, чи частково, навіть тоді, коли господарства взагалі не користувалися послугами МТС через неврожай, шкідників, стихійне лихо тощо. Після такого розподілу залишок розподілявся порівну між адміністрацією губернаторства й усіма членами громади ${ }^{50}$. Тільки після виконання усіх вищезазначених зобов'язань рештки зібраного урожаю ділилися відповідно до кількості відпрацьованих трудоднів членів громади.

Нарахування трудоднів відбувалось упродовж усього року наприкінці кожного місяця. Наприклад, селянину Колосу Василю (вид діяльності встановити не вдалося) 3 «трудової общини» с. Маяки Біляївського району за період (з квітня по листопад 1942 р.) нарахували 192,25 трудодні. Помісячно ця картина виглядає таким чином:

\footnotetext{
48 ДАМО. Ф. 2512. Оп. 1. Спр. 1. Арк. 14.

49 ДАМО. Ф. 1718. Оп. 1. Спр. 19. Арк. 108.

50 ДАОО. Ф. 1932. Оп. 1. Спр. 15. Арк. 13.
} 
за квітень - 15,40 трудодня; травень - 45,40; червень - 20,20; липень - 26; серпень 15,25; вересень - 20,50; жовтень - 12,50; листопад - 3751. Більшу частину трудоднів, як свідчать цифри, було нараховано саме у теплі місяці року, а саме у період заготівлі кормів для тварин на зиму, робота у полі (прополювання та просапування городніх і польових культур) і під час збирання урожаю. У зимові місяці цей же селянин не брав участі у трудовій діяльності громади, а відтак за цей проміжок часу йому не нараховувались трудодні.

Яким саме чином спрацьовував механізм виплат за трудодні ілюструє схема розподілу продуктів на отримані трудодні серед селян господарства № 4 с. Гандрабури. Так, за 9 місяців 1941 р. за свою тяжку працю вони заробили й отримали за один трудодень 2 кг пшениці, 200 г соняшнику, 1 кг картоплі та 2 кг кукурудзи. Селянин цієї ж «трудової общини» Будигай П. отримав за 167 зароблених трудоднів 334 кг пшениці, 57 кг соняшнику, 167 кг картоплі та 334 кг кукурудзи. Інший селянин цієї ж громади Коротнян М. за 328 трудоднів отримав відповідно 656 кг пшениці, 112 кг соняшнику, 328 кг картоплі та 656 кг кукурудзи. Селянинові Затиці Ф. було нараховано лише 20 трудоднів, а, відтак, він отримав відповідно 40 кг пшениці, 4 кг соняшнику, 20 кг картоплі та 40 кг кукурудзи 52 . Пізніше, за останні місяці 1941 р. (жовтень, листопад і грудень) селянам громади за трудодень нарахували ще по 300 г соняшнику. Уже згадуваному селянину Будигаю П. за цей проміжок часу було зараховано 35 трудоднів, Коротняну М. - майже удвічі більше, а Затиці Ф. - 16,5 трудоднів 53 . Високі нарахування на зароблені трудодні пояснюються тим, що окупаційна адміністрація на перших порах свого правління намагалася заручитися лояльністю з боку місцевого населення, показуючи, що вона значно краще піклується про сільських працівників аніж попередня, радянська. Для порівняння у 1941 р., румунські окупанти трансністрійському селянину на один зароблений трудодень видавала 5,5 кг усіх видів сільськогосподарських культур. При радянській владі у 1937 р. переважна більшість селян на один трудодень отримували від 500 г до 2 кг усіх видів сільгоспкультур разом узятих 54 .

1942 року селяни зазначеного села вже отримували на трудодні таку кількість зерна: Затика М. за 715 трудоднів отримав 357,5 кг ячменю, 550 кг соняшнику та 20 кг квасолі, Іщенко I. - за 100 трудоднів отримав 50 кг ячменю, 77 кг соняшнику та 3 кг квасолі 55 . Тобто, на один зароблений трудодень припадало 500 г ячменю, 770 г соняшнику та 20 г квасолі. Порівняльний аналіз свідчить, що виплати натуральними продуктами за 1 трудодень, 1942 р. в тому ж селі було зменшено у чотири рази за деякими показникам (наприклад, ячменю та кукурудзи). На нашу думку, причиною кардинального зменшення оплати трудоднів стала зростаюча потреба у готовій сільськогосподарській продукції для внутрішніх потреб Румунського Королівства.

Трудівникам с. Стрюкове Голтянського повіту на один зароблений трудодень у 1941 р. видавали по 1 кг винограду впродовж періоду збирання цієї продукції. Селяни могли використати виноград як на власні потреби, так і продати румунським за-

\footnotetext{
51 ДАОО. Ф. 1932. Оп. 1. Спр. 585. Арк. 7-8.

52 Osypenko 0. Methods of «stimulating» the work of a rural worker in «Transnistria», 1941-1944 // Сторінки воєнної історії України: Зб. наук. статей. 2018. Вип. 20. С. 176.

53 ДАОО. Ф. 1932. Оп. 1. Спр. 585. Арк. 464-466.

54 Українське радянське суспільство 30-х pp. XX ст.: нариси повсякденного життя: Колективна монографія / Відп. ред. С.В. Кульчицький. Київ: Інститут історії України НАН України, 2012. С. 259. 55 ДАОО. Ф. 1932. Оп. 1. Спр. 184. Арк. 52.
} 
купникам 56.

Загалом, упродовж усього періоду окупації загарбниками було встановлено наступні фіксовані норми оплати трудодня, які діяли на території всього регіону: 340 г - ячменю, 200 г - соняшнику, 170 г - кукурудзи, 40 г - квасолі та 100 г - проса. Так, член трудової общини села Байтали Антонов В. станом на 1943 р. за 254 трудодні отримав 86,5 кг ячменю; 25,5 кг проса; 10,5 кг квасолі та 51 кг соняшнику; Осадчий П. - 277 трудоднів отримав 94 кг ячменю; 28 кг проса; 11,5 кг квасолі; 56 кг соняшнику57.

Така мізерна натуральна оплата праці ставила селянина, який перебував на окупованій території, у вкрай складні умови виживання. Адже у пересічного селянина була родина, яку необхідно було годувати. Водночас, слід враховувати наявність домашнього господарства селян, без якого важко було вижити і на яке також потрібно було виділяти певну кількість отриманого зерна. Разом із тим, обкладений безліччю натуральних і грошових податків, селянин вимушений був сплачувати їх під страхом покарання за рахунок отриманих продуктів на нараховані трудодні.

Ілюстрованим $\epsilon$ факт про те, що на утримання одного коня упродовж 6 місяців на період польових робіт щоденно виділялось: 1 кг кукурудзи та 1 кг ячменю58. Певною мірою, окупаційна адміністрація, тобто румунська влада, деякою мірою турбувалася скоріше про тяглову худобу, як основну робочу силу, більше, ніж про сільського працівника та його родину.

Отже, здійснюючи адміністрування на землях межиріччя Південного Бугу та Дністра, румунська адміністрація розглядала їх передусім, як території з необмеженими сільськогосподарськими ресурсами, які можна було безкарно експлуатувати та грабувати. Соціально-економічна політика румун, на загарбаних територіях зводилась до організації збору та викачування сільськогосподарської продукції через впровадження низки як натуральних так і грошових податків. Задля забезпечення виконання всіх планів загарбників, які були спрямовані зокрема на найголовніше - безперебійне викачування сільськогосподарської продукції, стало запровадження низки розпоряджень, які зобов'язали всіх сільських жителів працювати. Відмова населення від виконання всіх розпоряджень окупаційної влади, у тому числі й відмова виходити на роботу, загрожувала накладенню різноманітних покарань від грошових штрафів до позбавлення волі. Така варварська соціально-економічна політика окупантів ставила у вкрай важке становище сільське населення, прирікаючи його на зубожіле існування.

\section{REFERENCES}

Dallin, A. (1957). Odessa, 1941-1944: A Case Study of Soviet Territory Under Foreign Rule. California.

Deineka, N. (2013). Rumunskyi okupatsiinyi rezhym ta radianskyi rukh Oporu u pivdenno-zakhidnomu rehioni Ukrainy i Moldavii (1941-1944 rr.) [The Romanian occupation regime and the Soviet resistance movement in the southwestern region of Ukraine and Moldova (1941-1944)]. Odesa: Atlant [in Ukrainian].

Gratinich, S.A. (1985). Na levom beregu Dnestra. 1941 1944. Stranitsy sovmestnoi borby trudiashchikhsia smezhnykh raionov Moldavii i Ukrainy protiv nemetsko-rumynskikh fashistskikh zakhvatchikov [On the left bank of the Dniester. 1941-1944. Pages of the joint struggle of workers of adjacent regions of Moldova and Ukraine against the German-Romanian fascist invaders]. Kishinev: Kartia Moldoveniaske [in Russian].

56 ДАОО. Ф. 1932. Оп. 1. Спр. 467. Арк. 7.

57 ДАОО. Ф. 1932. Оп. 1. Спр. 144. Арк. 3.

58 ДАОО. Ф. 1932. Оп. 1. Спр. 674. Арк. 138. 
Kulchitskyi, S. (ed.) (2012). Ukrainske radianske suspilstvo 30-kh rr. XX st.: narysy povsiakdennoho zhyttia [Ukrainian Soviet Society of the 1930's. Essays of Everyday Life]. Kyiv: Instytut istorii Ukrainy NAN Ukrainy [in Ukrainian].

Lebedev, N.I. (1976). Krakh fashizma v Rumynii [The collapse of fascism in Romania] Moskva: Nauka [in Russian].

Levchenko, Yu. (2013). Upravlinskyi aparat rumunskykh administratyvno-terytorialnykh odynyts Ukrainy pid chas okupatsii 1941-1944 rr. [The managerial unit of the Rumanian administrative and territorial office of Ukraine is at the time of repayment 1941-1944]. Naukovyi visnyk Skhidnoievropeiskoho natsionalnoho universytetu imeni Lesi Ukrainky. Seriia: istorychni nauky, 21 (269), $70-75$ [in Ukrainian].

Levit, I.E. (1981). Krakh politiki agressii diktatury Antonesku [Her Collapse of Antonescu's Dictatorship Aggression Policy]. Kishinev: Shtiintsa [in Russian].

Levit, I.E. (1981). Uchastie fashistskoi Rumynii v agressii protiv SSSR. Istoki, plany realizatsiia [The participation of fascist Romania in the aggression against the USSR. Origins, plans, implementation]. Kishinev: Shtiintsa [in Russian].

Mykhailutsa, M.I. (2008). Pravoslavna tserkva na Pivdni Ukrainy v roky Druhoi svitovoi viiny (1939-1945) [Orthodox Church in the South of Ukraine during the Second World War (1939-1945)]. Odesa: VMV [in Ukrainian].

Mykhailutsa, M.I. (2015). Rekonstruktsiia diialnosti Domanivskoho protoiiereistva Holtianskoho povitu $\mathrm{v}$ period rumunskoi okupatsii (1941-1944 rr.) [Reconstruction of the work of the Domaine Archpriest of the Holtan County during the Romanian occupation (1941-1944)]. Kraeznavstvo, 1-2, 184-189 [in Ukrainian].

Nitochko, I.I. (2008). Okupatsiia: Berezivskyi raion. 1941-1944 rr. [Occupation: Berezivsky district. 19411944]. Odesa: Astroprynt [in Ukrainian].

Odessa: zhizn v okkupatsii 1941-1944. Istoriia kollaboratsionizma (2013) [Odessa: life in the occupation. 1941-1944. History of collaborationism]. Moskva: Politicheskaia entsyklopediia [in Russian].

Odesskaia oblast $v$ Velikoi Otechestvennoi voine 1941-1945 gg. (1970) [Odessa region in the Great Patriotic War of 1941-1945]. Odessa: Maiak [in Russian].

Osypenko, 0. (2018). Methods of «stimulating» the work of a rural worker in "Transnistria», 19411944. Storinky voiennoi istorii Ukrainy, 20, 173-183 [in Ukrainian].

Osypenko, O.V. (2018). Silske naselennia ta «Trudovi hromady» Pivdnia Ukrainy v hubernatorstvi «Transnistriia» 1941-1944 rr.: sotsialno-istorychnyi aspekt [Rural population and «Labor communities» of the South of Ukraine in the governorate «Transnistria» 1941-1944: socio-historical aspect]. (Extended abstract of Candidate's thesis). Mykolaiv [in Ukrainian].

Perekhrest, O.H. (2010). Silske hospodarstvo Ukrainy v roky Velykoi Vitchyznianoi viiny (1941-1945 rr.) [Agriculture of Ukraine during the Great Patriotic War (1941-1945)]. Kyiv: Instytut istorii Ukrainy NAN Ukrainy [in Ukrainian].

Rekotov, P.V. (1997). Orhany upravlinnia na okupovanii terytorii Ukrainy (1941-1944 rr.) [Governments in the Occupied Territory of Ukraine (1941-1944)]. Ukrainskyi istorychnyi zhurnal, 3, 90-101 [in Ukrainian].

Shchetnikov, V.P. (2012). Ekonomichna skladova rumunsko-nimetskoi prysutnosti $v$ «Transnistrii» 19411944 rr. [The economic component of the Romanian-German presence in Transnistria 1941-1944]. Storinky voiennoi istorii Ukrainy, 15, 173-188 [in Ukrainian].

Solovei, R. (2004). Activitatea Guvernamintului Transnistriei on domeniul social-economic si cultural: (19 auq. 1941 - 29 ian. 1944). Iasi [in Moldova].

Tarnavskyi, I.S. (2010). Administratyvnyi podil ta orhany upravlinnia na terytorii pivdenno-zakhidnoi Ukrainy za chasiv rumunskoi okupatsii [Administrative division and government in the territory of southwestern Ukraine during the Romanian occupation]. Istorychni i politolohichni doslidzhennia, 3-4, 210-216 [in Ukrainian].

Tarnavskyi, I.S. (2012). Polityka Tretoho reikhu ta yoho soiuznykiv na okupovanykh ukrainskykh zemliakh $v$ roky Druhoi svitovoi viiny [Politics of the Third Reich and its allies in the occupied Ukrainian lands during the Second World War]. Donetsk: TOV «VPP «PROMIN» [in Ukrainian].

Vintskovskii, T., Kiazymova, G., Mykhailutsa, M. \& Schetnikov, V. (2010). Okupatsiinyi rezhym v hubernatorstvi «Transnistriia» [Occupation regime in the Transnistrian province]. In Ukraina $u$ Druhii svitovii viini: pohliad z XXI st. Istorychni narysy. Vol. 1 (pp. 413-446). Kyiv: Naukova dumka [in Ukrainian].

Zhukovskyi, A. (1987). Ukrainski zemli pid rumunskoiu okupatsiieiu v chasy Druhoi svitovoi viiny : Pivnichna Bukovyna, chastyna Bessarabii i Transnistrii [Ukrainian lands under Romanian occupation 
during the Second World War: Northern Bukovina, part of Bessarabia and Transnistria]. Ukrainskyi istoryk, 1-4, 83-96 [in Ukrainian].

\section{Oleksandr Osypenko}

(Odesa National Maritime University, Odesa, Ukraine)

ORCID: https://orcid.org/0000-0002-1213-0481

\section{Social and Economic Policy of the Romanian Administration in the Rural Area of South- western Ukraine in 1941-1944}

The paper reveals the social and economic policy of the Romanian administration regarding the rural population in the interfluve of the Dniester and the Southern Buh in 1941-1944. One of the focal points of the Romanian occupation economic policy was the establishment of the agricultural sector of production, for which Directorate General for Agriculture was established. In order to reorganize the Soviet system of agricultural management, the Administration developed and introduced Order № 55, according to which the transformation of collective farms into «labour communities» took place. It has been found out that since the first days of occupation, the Romanian authorities impudently started to plunder the rural population. For the rural population, a number of taxes in kind were developed and introduced. For the needs of the invaders, villagers gave fleece, socks, mittens, and felt boots. According to Order №66, the peasants were obliged in the form of taxes to give milk, eggs, poultry, meat (pork, beef, mutton). Despite the existence of that order, besides taxes in kind, the peasants paid the money for land, cattle grazing and keeping dogs.

To ensure the fulfilment of all plans of the invaders aimed, in particular, at the most important - the continuity of agricultural products supply, several regulations that obliged all rural residents to work were introduced. The refusal of the population to execute all orders of the occupation authorities, including the refusal to go to work, could cause the infliction of various punishments from monetary fines to imprisonment. The Romanian authorities in the occupied lands of Southwestern Ukraine tried to save not only collective farms but also created by the Stalin authorities a pre-war system of remuneration of labour, «workday».

Agricultural workers got payment in kind. The peasants got those types of agricultural products, which were grown by «labour communities».

Such barbaric social and economic policy of the invaders placed the rural population in a very difficult position, condemning it to an impoverished existence.

Keywords: Transnistria, occupation, county, rural population, labour community, orders, $\operatorname{tax}$ 